\title{
Development of gonads and evidence of protogyny in Spangled emperor (Lethrinus nebulosus) from the coastal waters off Negombo, Sri Lanka.
}

\author{
R. R. M. K. P. Ranatunga* and Shreemali Rathnayaka \\ Centre for Marine Science and Technology, Department of Zoology, University of Sri \\ Jayewardenepura, Nugegoda, Sri Lanka. \\ *Correspondence (ranatunga@sci.sjp.ac.lk) \\ https://orcid.org/0000-0002-0432-6003
}

\begin{abstract}
Gonad development and maturation of the spangled emperor Lethrinus nebulosus (Forsskål, 1775) inhabiting coastal waters off Negombo, Sri Lanka was investigated to understand the reproductive strategies. Sexual ontogeny was investigated using histological examinations of the gonads and changes in sex ratio with body size. Cellular characteristics and the most advanced germ cells presented in the gonads were considered for determining the sex and maturity stages. The transitional gonads were characterized by changes in internal gonad structure such as the appearance of spermatocyte and degenerated oocytes in the same developmental stage. Thick strands of stromal tissue within the lamellae and branched secondary strands were observed in transitional individuals. Increased blood vessels and sperm sinuses within the gonad wall were also an indications of sex transition. Therefore, L. nebulosus living in coastal waters off Negombo exhibited an early indication of protogynous hermaphroditism among adults. The sizes at $50 \%$ sexual maturity of males and females were estimated to be $29.5 \mathrm{~cm}$ and $39.5 \mathrm{~cm}$ respectively. A dramatic change in the sex ratio of the adult size classes suggested that female to male sex transition observed between $28.5-40.4 \mathrm{~cm}$ body sizes. Sex ratios were 1.23: 0.46: 1 for female: transitional: males indicating slightly female-biased overall sex ratios. Female dominance in smaller size classes and male dominance in larger size classes were also evident Mean size at first capture recorded for L. nebulosus $(19.6 \mathrm{~cm})$ was well below the mean sizes of maturity for both male and female. Size-specific differences in sex ratios and reproductive potential indicate that conventional regulations that impose size limits for capture would not be very effective for the management of L. nebulosus.
\end{abstract}

Keywords: Spangled emperor, Lethrinus nebulosus, Maturation, Gonad development, Protogynous hermaphroditism, Sex transition

\section{INTRODUCTION}

Fish may be either gonochoristic (separate male and female throughout life) or hermaphroditic (complete or partial reproductive organs of both male and female). Hermaphroditic individuals may function as males or females either simultaneously or sequentially. Sequential hermaphrodites may be protogynous in which females change to males, or protandrous in which males change to females as adults (Hoar \& Randall, 1969; Jennings et al., 2005; Molloy et al., 2007). There are increasing evidences that several reef-associated fish change sex during their lifetime (e.g., Young and Martin 1982; Asoh et al. 2001; Kulmiya et al. 2002; Bean et al. 2003; Grandcourt et al. 2006; Mackie et al.
2006; McBride and Johnson 2007; Pears et al. 2007).

The family Lethrinidae (emperor fishes and large-eye breams) is one of the most common fishes exploited in artisanal demersal fisheries of the tropics (Ebisawa and Ozawa 2009). Reproductive studies have identified several lethrinid species as protogynous hermaphrodites (e.g., Thresher 1984; Sadovy 1996; Ebisawa 2006; Sadovy de Mitcheson and Liu 2008; Motlagh 2010a) resulting in female-biased adult sex ratios (Sadovy 1996).

The spangled emperor Lethrinus nebulosus (Forsskål 1775) is a tropical fish distributed throughout the Indo-West Pacific from the Red Sea and East Africa to southern Japan and Samoa, which can reach up to $80.0 \mathrm{~cm}$ total length (TL) 


\section{R. R. M. K. P. Ranatunga and Shreemali Rathnayaka}

and up to $8.4 \mathrm{~kg}$ weight (Randall 1995). It is found to inhabit coral reefs, seagrass beds, mangroves and nearshore waters up to $75 \mathrm{~m}$ depth. Adults are found as solitary or in small schools, whereas juveniles form large schools in shallow, sheltered sandy areas, often associated with seagrasses, algae, or sponge habitats (Randall 1995).

Previous studies on the reproductive biology of L. nebulosus in Northern Australia (Young and Martin 1982), Japan (Ebisawa 1990), Great Barrier Reef, Australia (Grandcourt 1999; Currey et al. 2013), Egypt (Red Sea) (Salem 1999; Mahmoud 2009), Persian Gulf and Oman Sea (Mcllwain et al. 2006; Motlagh et al. 2010b), Western Australia (Marriott et al. 2010), Arabian Gulf (Grandcourt et al. 2010) have shown greater variations among studies. Young and Martin (1982) concluded that protogynous hermaphroditism is the typical mode of sexuality with no clear relationship between sex ratio and size for L. nebulosus found in NorthWestern Australia. However, a linear relationship between size and sex ratio was demonstrated for other lethrinids where females predominate at smaller sizes and males at larger sizes. There was also no clear evidence of sex change in spangled emperors within the size range $17-54 \mathrm{~cm}$ in the Great Barrier Reef (McPherson et al. 1988). However, other studies (e.g., Ebisawa 1990; Grandcourt 1999; Marriott et al. 2010) have shown juvenile protogynous hermaphroditism, where the transition from the ovary to testis occurs before ovarian maturation, and not the true sex-reversal often observed in protogynous hermaphrodites.

A good understanding of reproductive biology is imperative for the management of fish species mainly because of the potential disruption to reproduction caused by fishing. Stock assessment and management strategies are traditionally developed for gonochoristic species with equivalent male to female sex ratios. A better understanding of reproductive biology is therefore important and different management trajectories are needed for those species with different reproductive characteristics (Sadovy 1996).

Issues may arise when excessive fishing is exerted on hermaphroditic populations (Bannerot et al. 1987). In protogynous species, where males tend to be larger than females, size-selective fishing may result in sperm limitation due to the differential loss of larger, older males (Koenig et al. 1996). Some simulation studies have shown a failure to account for the selectivity characteristics in relation to size at maturity and the size at sex change can lead to unexpected collapse of populations with protogynous sexual pattern (Alonzo and Mangel 2005).

There are no previous studies on the reproductive biology of $L$. nebulosus inhabiting in Sri Lankan coast of the Indian Ocean, and the present study was to augment this knowledge gap.

\section{MATERIALS AND METHODS}

L. nebulosus samples were collected from artisanal fishers in two of the fish landing sites in Negombo (Fig. 1) in monthly intervals between August 2015 and February 2016. Body size (Standard Length, $\mathrm{SL}$ ) was measured to the nearest centimetre using a measuring board for all $L$. nebulous found in the landing sites during the sampling day, and body weight was recorded to the nearest gram with an electronic scale. All together 430 specimens were sampled out of which 70 specimens representing different size classes were used for histological preparations of gonads.
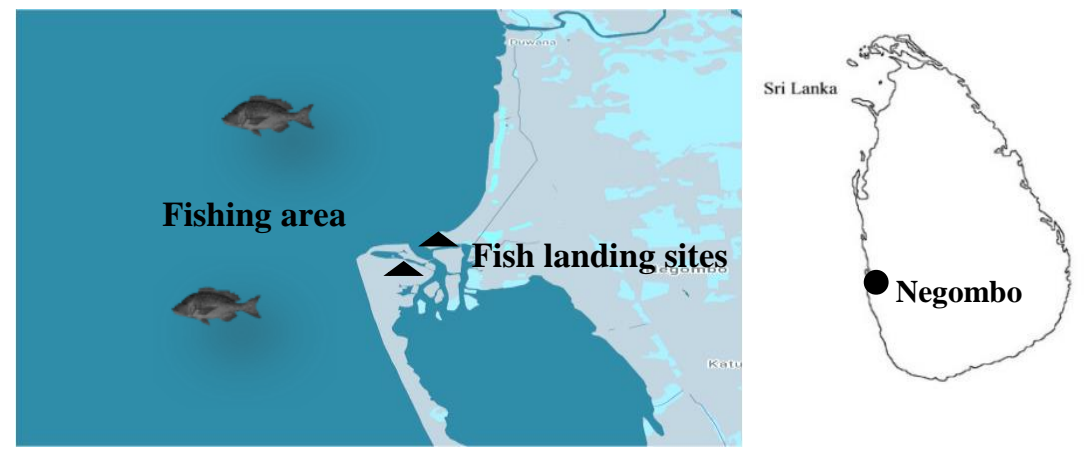

Fig 1 Fish landing sites where the samples were obtained and the fishing area. 
Since it was not possible to identify the gonad maturity stages macroscopically, histological analyses were carried out. In the laboratory, gonads were dissected, and weighed to the nearest gram and preserved in FAACC (Formaldehyde 4\%, Acetic Acid 5\%, Calcium Chloride 1.3\%) solution following Mackie (2006). Series of transverse thin medial sections of 5-7 $\mu \mathrm{m}$ were obtained from each gonad using a rotary microtome. Sections were mounted on glass slides, stained with Heidenhain's iron hematoxylin and eosin and permanent mounts were prepared using standard histological techniques. Preparations were examined microscopically using high power $(\times 100-\times 400)$ with a Microscope Image Projection System (MIPS, Magnus ${ }^{\circledR}$ Analytics).

Ovaries were assigned to sexual development stages based on the most developed oocytes as well as the presence or nature of intra-lamellar stromal tissue, the relative thickness of the ovary walls and muscle bundles, atretic oocytes, postovulatory follicles and yellow-brown bodies (Adams et al. 2000; Marino et al. 2001; Bean et al. 2003; McBride and Johnson 2007). The testes were classified into maturity stages based on the classification of Grier and Taylor (1981). The transitional individuals were confirmed when the gonad contains both degenerating mature female tissue and proliferating male tissue (Bean et al. 2003).

The mean length at first sexual maturity $\left(\mathrm{L}_{\mathrm{m} 50}\right)$ for both males and females was estimated by considering the proportion of mature fish in each 4 $\mathrm{cm}$ size-class. The sex ratio was calculated for all males and females separately and also for $4 \mathrm{~cm}$ size intervals. Frequency plots were used to demonstrate the distribution of each sex over the size ranges.

\section{RESULTS}

\section{Ovary structure}

Macroscopic investigations showed that $L$. nebulosus ovaries were cylindrical with approximately equal size. Microscopic investigations revealed five developmental stages as immature, resting, ripe, running ripe, and postspawning. Immature ovaries were dominated by pre-vitellogenic oocytes, and strands of stromal tissue within the lamellae were filamentous (Fig. 2a). Resting ovaries were dominated by previtellogenic oocytes. Primary growth oocytes of resting ovaries had a thick wall. Strands of stromal tissue within the lamellae were usually thin and filamentous, although in some cases, these tissues showed signs of thickening and were associated with an increased number of intra-lamellar blood vessels (Fig. 2b). Ripe ovaries were in a state of active vitellogenesis with yolk globule, and oocytes belong to all stages of development were present. Strands of stromal tissue within the lamellae were thin and filamentous (Fig. 2c). Running ripe ovaries contained hydrated oocytes, yolk globule, and migratory nucleus stage oocytes were also present (Fig. 2d). In postspawning ovaries, yolk globule oocytes were present in the lamellae with postovulatory follicle (POF) often with atretic oocytes (Fig. 2e). 
$\mathbf{a}$

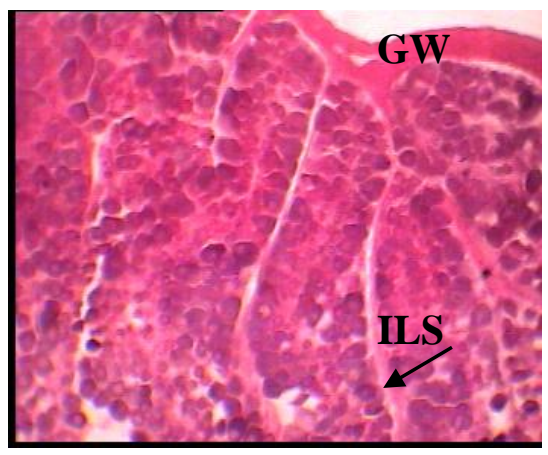

c

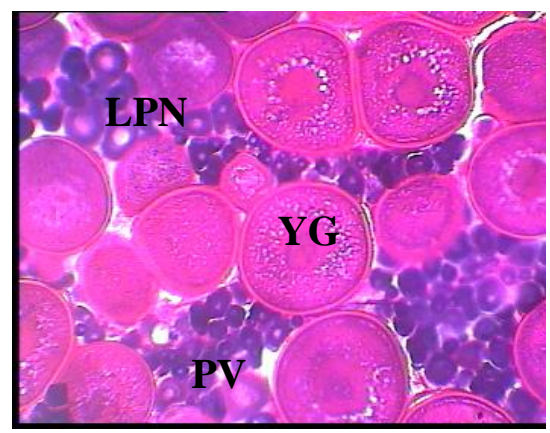

e

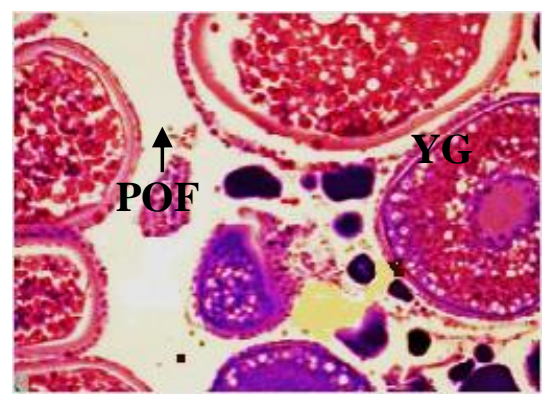

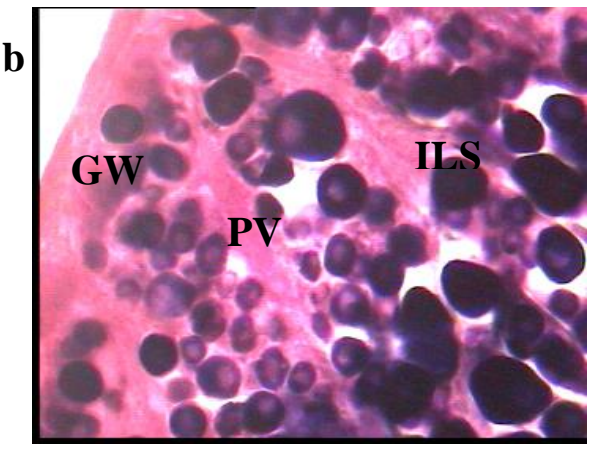

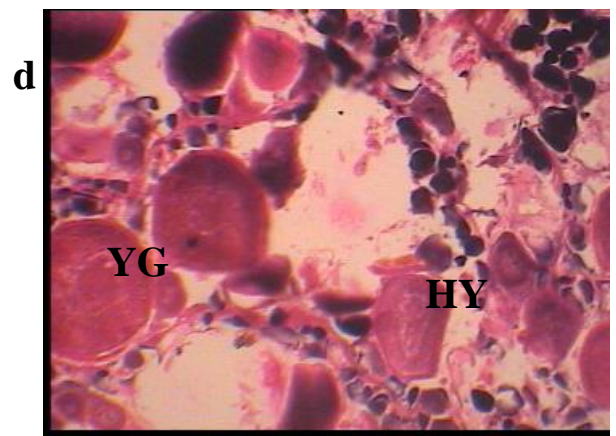

Fig 2 Structure and cellular characteristics of developmental stages of L. nebulosus ovaries: (a) Immature, (x100) (b) resting, (x400) (c) ripe (x100) (d) running ripe (x100). (e) Postspawning (x200). GW, gonad wall; ILS, inter lamellar stromal strands; LPN, late peri nucleolus; PV, previtellogenic; YG, yolk globule; HY, hydrated oocyte; POF, postovulatory follicle.

\section{Testis structure}

Four maturity stages were recorded for $L$. nebulosus testes as pre-spawning resting, ripe, spent and post-spawning resting. Pre-spawning resting testes composed of densely packed spermatocysts containing spermatogonia, spermatocytes, and spermatids. Spermatozoa occurred more frequently in spermatocysts (Fig. 3a). Ripe testes were dominated by spermatozoa filling all sperm sinuses. Spermatocysts containing early stages of sperm development were rare (Fig. $3 b)$. Spent testes characterized by loosely arranged tissues which were highly vascularized and containing considerably a fewer spermatocysts of any sperm stage (Fig. 3c). Post-spawning resting testes were considerably rare, and the spermatocysts were no longer loose or diffusely arranged (Fig. 3d). 
a
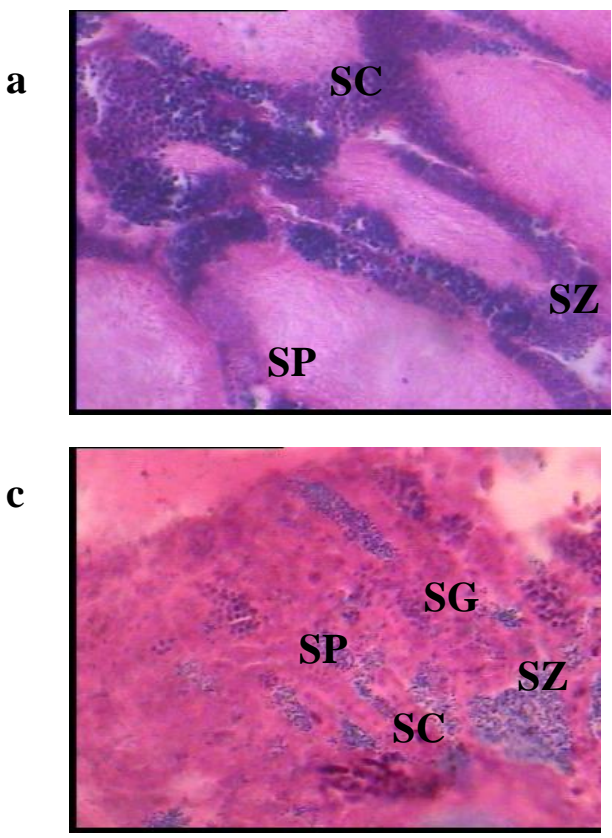
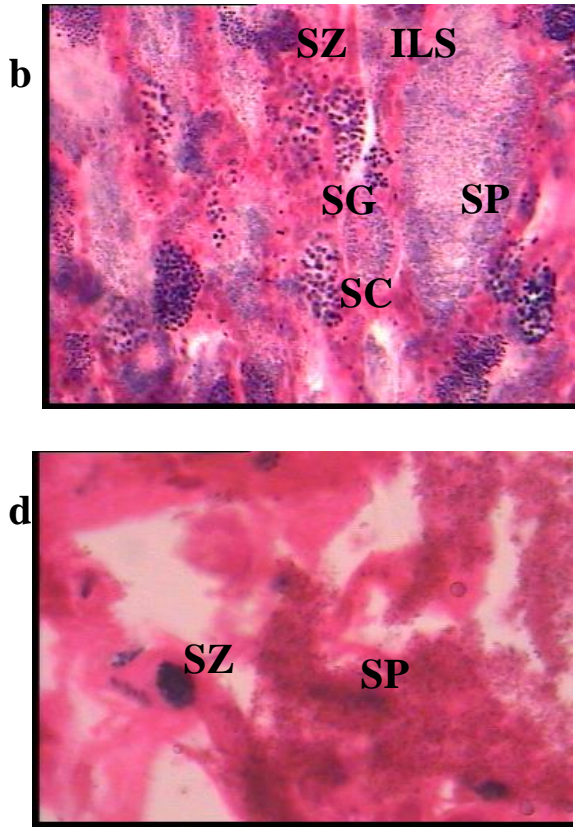

Fig 3 Structure and cellular characteristics of developmental stages of L. nebulosus testes: (x400) (a) pre-resting, (b) ripe, (c) spent and (d) post resting. SG, spermatogonia; SC, spermatocytes; SP, spermatids; SZ, spermatozoa; ILS, intra lamellar stromal strands

\section{Transitional gonad structure}

In all transitional gonads, oocytes had degenerated considerably prior to the proliferation of spermatogenic tissue (Fig. 4a). This characteristic is the first indication of sex change in many cases. In females, stromal strands appear as filamentous structures between the lamellae folds, but during the transition phase, these strands become thickened and secondary strands branch off from the main strands of stromal tissue into the surrounding tissue (Fig. 4b). These stromal strands were well developed and highly infiltrated with blood vessels (Fig. 4a). At the distal end of the strands of stromal tissue, sperm sinuses had formed within the gonad wall (Fig. 4c).

Proliferating spermatocysts were commonly located in the peripheral margins of the lamellae. During the study, twelve specimens of L. nebulosus had both female tissue and spermatocysts belong to one sperm developmental stage. 
a

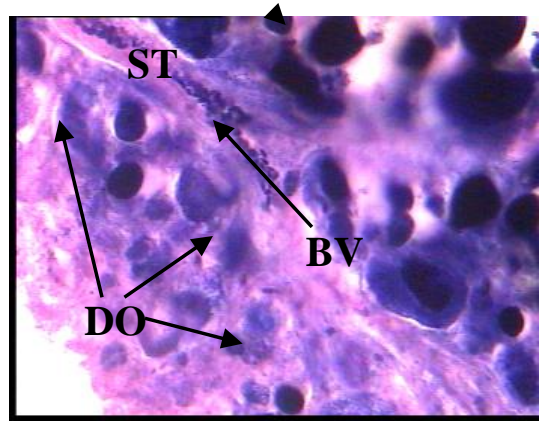

c

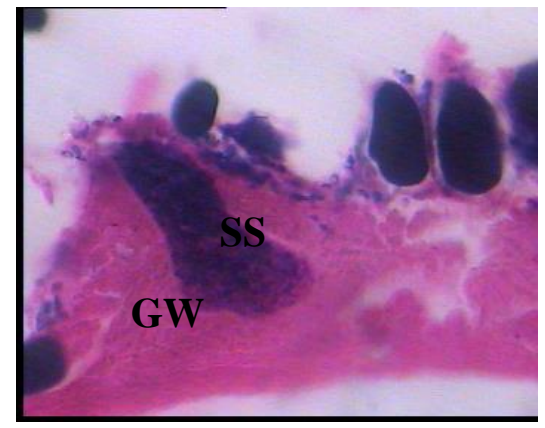

b

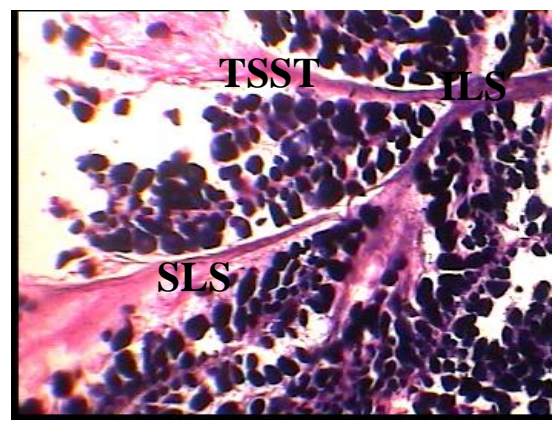

Fig 4 Structure and cellular characteristics of transitional L. nebulosus gonads: (x400).

(a) Degenerating oocytes (DO) and stromal strands (ST) with increased blood vessels (BV), (b) Presence of thickened strands of stromal tissue (TSST) within the lamellae, branched secondary strands, intralamellar stromal strands (ILS), and secondary lamellar stromal strands (SLS), further prove that sex transition has been initiated. SS, sperm sinus; GW, gonad wall.

\section{Size at maturity}

According to Fig. 5, mean sizes that $50 \%$ of $L$. nebulosus males and females attained the first sexual maturity $\left(\mathrm{L}_{\mathrm{m} 50}\right)$ were at $29.5 \mathrm{~cm}$ and $39.5 \mathrm{~cm}$ standard lengths, respectively. This indicates that males mature at smaller sizes compared to females.

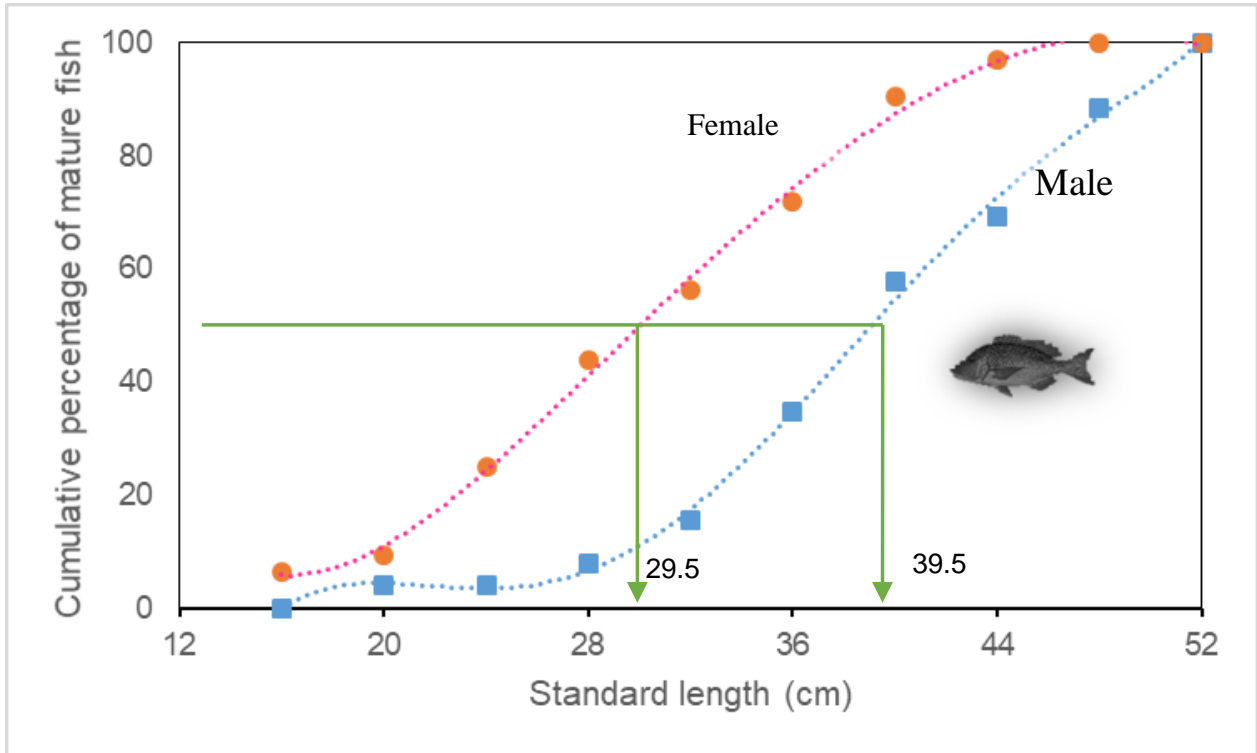

Fig 5 Cumulative percentage of mature L. nebulosus males and females with the size showing the mean, standard lengths at which $50 \%$ of the individuals attain sexual maturity $\left(\mathrm{L}_{\mathrm{m} 50}\right)(\mathrm{N}=70)$. 
As shown in Fig. 6, sex transition occur between 28.5- $40.4 \mathrm{~cm}$ size classes. At this size, female $L$. nebulosus should be already or nearly matured. It is evident that the females were predominated in the smaller size classes, and they either changed sex to male or remained female and matured at a larger size whereas males were dominant in the larger size classes. The sex ratio for female: transitional: the male was 1.23: $0.46: 1$, indicating slightly female biased overall sex-ratio.
When examining length frequency distribution of monthy landings, the size of L. nebulosus at first capture was found to be in the size class 16.5-20.5 $\mathrm{cm}$ (Fig. 7). The mean size at first capture recorded for L. nebulosus, which is $19.6 \mathrm{~cm}$ was well below the sizes for both male and female maturity sizes $29.5 \mathrm{~cm}$ and $39.5 \mathrm{~cm}$ respectively.

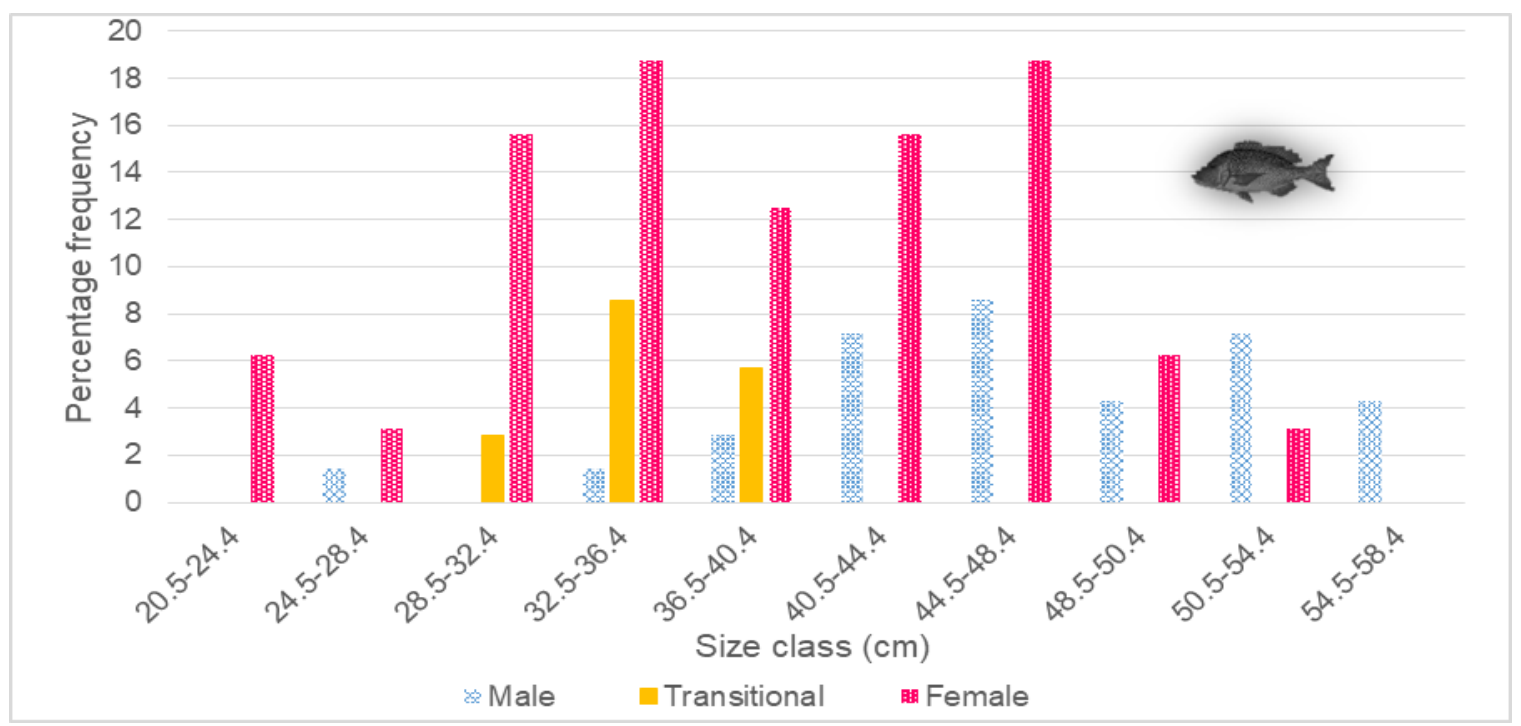

Fig 6 Sex specific size frequency distribution $(\mathrm{N}=70)$. 


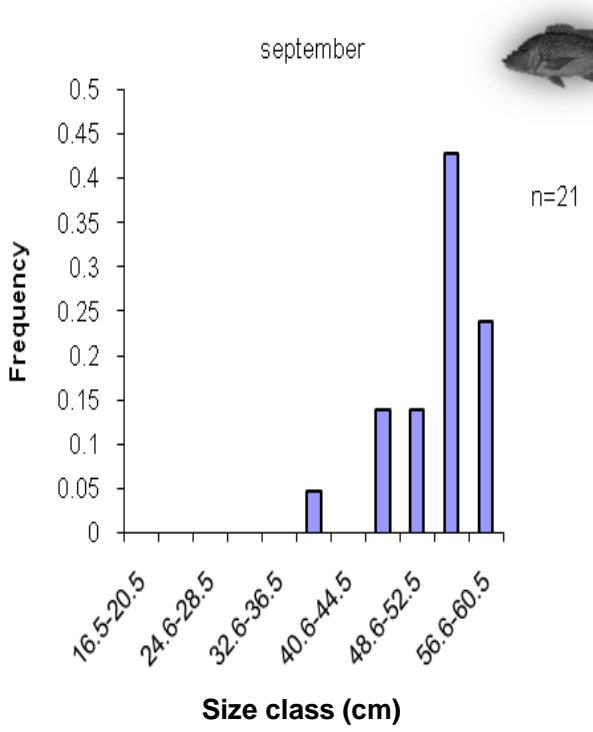

November

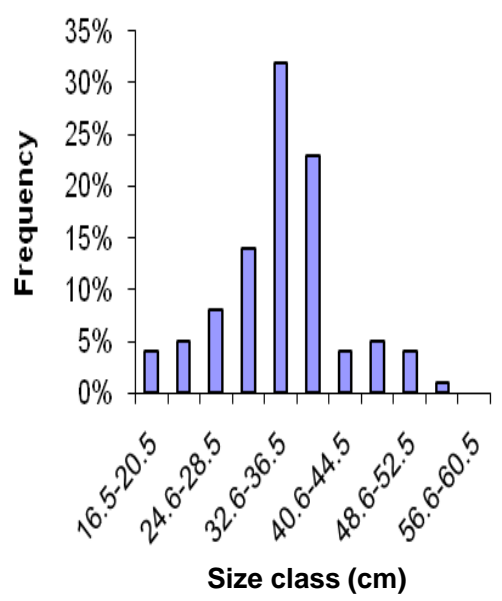

January

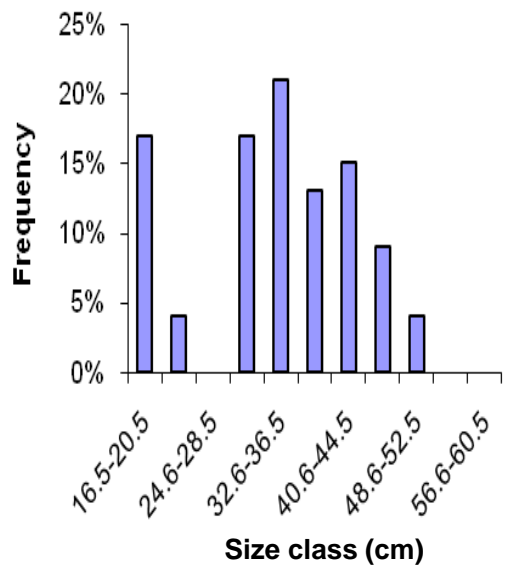

october
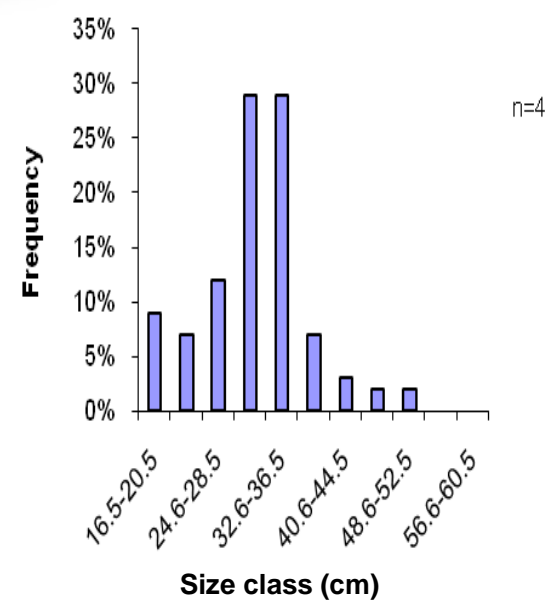

December

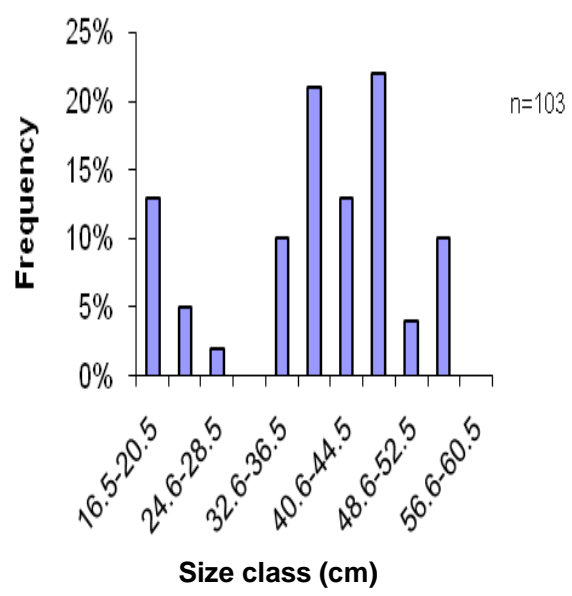

February

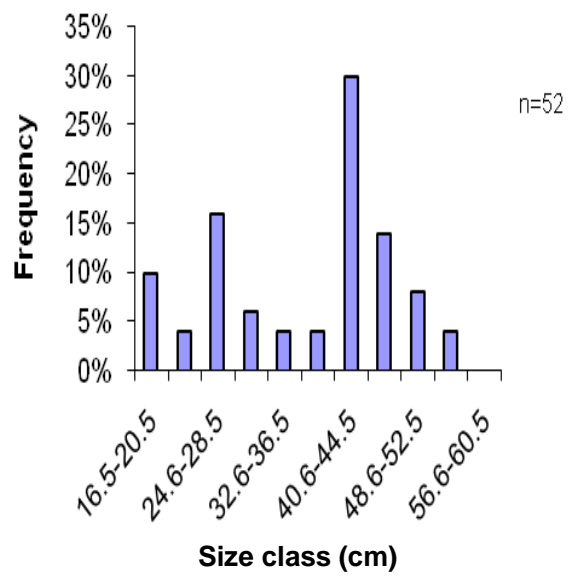

Fig 7 Monthly variation in the length frequency distribution of L. nebulosus landings 


\section{R. R. M. K. P. Ranatunga and Shreemali Rathnayaka}

\section{DISCUSSION}

All stages of mature male and female gonads studied had no specific features to identify them macroscopically. Therefore, confirmation of the sexual pattern required histological analysis of gonad morphology as with other studies (Pears et al. 2007). Five developmental stages were identified for ovaries and four stages for male $L$. nebulosus in this study. Oocyte and sperm developmental stages of $L$. nebulosus was in-line with few other similar studies (Adams et al. 2000; Asoh et al. 2001; Marino et al. 2001; Bean et al. 2003; Knight et al. 2007).

Sex change, where individuals function as both sexes sequentially, is a common reproductive strategy in tropical reef fishes, occurring in nearly $50 \%$ of families (Jennings et al. 2005; McIlwain et al. 2006; Molloy et al. 2007). The simultaneous presence of developing sperm crypts and degenerating mature female tissues and peripheral sperm sinuses described here suggest that sex change in $L$. nebulosus is consistent with patterns described for other protogynous hermaphroditic reef fishes (Adams et al. 2000; Kulmiye et al. 2002; Bean et al. 2003). According to Adams et al. (2000), the presence of other features such as strands of stromal tissue within the lamellae, increased number of blood vessels along the stromal strands and within degenerating female tissue during sex change, are common in many protogynous reef fishes. During the study, 12 specimens of transitional stage L. nebulosus were identified among the sample subjected to histological examination. The presence of strands of stromal tissue within the lamellae in $L$. nebulosus is also an important structural characteristic that appears to vary in function depending on the gonad stage. In females, stromal strands appear as filamentous structures between lamellal folds, but during the transitional phase, these strands become thickened and secondary strands branched off from the main strands of stromal tissue into the surrounding tissue and increased number of blood cells. Bean et al. (2003) described that these blood cells are primarily phagocytic and also function as nutrient cells, whose role may be both to break down existing female tissue and to provide nutrients to cells involved in male tissue development. The increased number of blood vessels during sex change may, therefore, facilitate the complete transition from female to male.

The presence of both female tissue and spermatocytes in a single developmental stage indicates the first sign of sex change in females. However, as pointed out by Bean et al. (2003), proliferating spermatocytes of more than one cell stage would be required to confirm any sex change. This study shows an early indication that sex change has initiated in L. nebulosus. However, further studies may facilitate the complete understanding of protogynous hermaphroditism in L. nebulosus inhabiting in coastal waters of Sri Lanka.

Young and Martin (1982), found evidence for protogynous hermaphroditism in eight lethrinid species from Australian waters and suggested that the protogynous hermaphroditism is a usual mode of sexuality in lethrinid fishes. However, the mechanism of controlling sex change is not clearly understood in any of the lethrinids studied. Ebisawa (1990) suggested that L. nebulosus was a juvenile hermaphrodite with sex being determined around $24-30 \mathrm{~cm}$ fork lengths but the fish was not maturing until approximately $40 \mathrm{~cm}$ fork length.

According to the present study, the mean sizes that $50 \%$ of L. nebulosus males and females attain the first maturity were $29.5 \mathrm{~cm}$ and $39.5 \mathrm{~cm}$ standard length respectively, indicating that males mature at smaller sizes than females. Several other studies have shown that the L. nebulosus males attain sexual maturity at relatively smaller sizes. Grandcourt et al. (2010), who studied L. nebulosus in Arab Emirates, Abu Dhabi, found that males mature at $28.6 \mathrm{~cm}$ whereas females at $31.3 \mathrm{~cm}$. Mean sizes of maturity of $27.6 \mathrm{~cm}$ for males and $28.6 \mathrm{~cm}$ for females were reported in the Southern Arabian Gulf (Grandcourt et al. 2006), and Mahmoud (2009) reported from the Red Sea in Egypt that mean size of maturity was $25.1 \mathrm{~cm}$ for males and $26.2 \mathrm{~cm}$ for females.

Grandcourt et al. (2006) found that males tend to be larger than females for protogynous species. The present study also revealed that the majority in the larger size classes were males, although there was considerable overlap in the size distribution of the sexes. Sex-specific size frequency distribution in the present study (Fig. 6) indicates that transition occurs within the size range $28.5-40.4 \mathrm{~cm}$ when most of the females are not matured. According to Young and Martin (1982), the sexual 


\section{R. R. M. K. P. Ranatunga and Shreemali Rathnayaka}

transformation of lethrinids occurs over a wide range of sizes with female predominating in the larger size classes. Similarly, Kulmiye et al. (2002) and Jennings et al. (2005) reported female predominance in the larger size classes from New Caledonian waters. The first sex is always more abundant in fishes that change sex, thus giving female biased sex ratio for protogynous species. The present study suggested that the males were predominating in larger size classes. Also,the presence of larger females in the population demonstrates that only some females change sex while others remain as females throughout their lifetime.

Ebisawa (1990) identified intersexual gonads in juveniles of L. nebulosus from Okinawa waters and concluded juvenile protogynous hermaphroditism. Grandcourt (1999) also found evidence of juvenile protogyny from the Great Barrier Reef. The juvenile hermaphroditism described by Ebisawa (1990) and Grandcourt (1999) is regarded as a nonfunctional sex change (also referred to as functional gonochorism), which will not be followed by post-maturational sex change (Sadovy and Liu 2008). Marriott et al. (2010) from Ningaloo Marine Park, Australia demonstrated a non-functional protogynous hermaphroditic strategy. A study by Currey et al. (2013) also indicated non-functional protogynous hermaphroditism for $L$. nebulosus from Great Barrier Reef, Australia.

However, a study from the southern Arabian Gulf showed no histological evidence of adult sex change, and sex ratios did not differ significantly across size classes (Grandcourt et al. 2010). A study off the Sinai Peninsula in the Red Sea (Salem (1999) and a study in Egypt from the Red Sea (Mahmoud 2009) also revealed no evidence of any sex change from the study samples.

According to the size-frequency distribution for L. nebulosus landings in this study, it was evident (Fig. 7) that the smallest size of the individuals caught $(19.6 \mathrm{~cm})$ was immature. However, larger fish (mature) were more abundant in most of the months studied throughout the study period except for December and January. From this study it is evident that larger individuals caught in the fishery are more likely to be males. Since fishing generally targets larger fish, disproportionate removal of males would affect reproductive traits of the population, which may lead towards more female biased populations resulting in sperm limitations. McIlwain et al. (2006) also indicated that the presence of sequential hermaphrodites would considerably complicate the management of a fishery. Therefore, studies of this nature may benefit the proper management of the already distressed fish populations. This also illustrates the importance of understanding species-specific life histories to infer responses to exploitation.

\section{CONCLUSION}

L. nebulosus living in coastal waters off Negombo, Sri Lanka provides an early indication of protogynous hermaphroditism. Fifty percent of males and females attain sexual maturity between $29.5 \mathrm{~cm}$ and $39.5 \mathrm{~cm}$ standard lengths, respectively. The mean size at first capture for $L$. nebulosus landings was $19.6 \mathrm{~cm}$ which was well below the male and female size-at-maturity. Sex transition initiated between $28.5-40.4 \mathrm{~cm}$ size classes. Female dominate in smaller size classes, and male dominance in larger size classes was evident. Overall sex-ratio was slightly female biased.

\section{REFERENCES}

Adams, S., B. D. Mapstone, G. R. Russ and C. R. Davies (2000). Geographic variation in the sex ratio, sex-specific size, and age structure of Plectropomus leopardus (Serranidae) between reefs open and closed to fishing on the Great Barrier Reef. Journal of Fishery and Aquatic Science 57: 1448-1458.

Alonzo, S.H. and M. Mangel (2005). Sex-change rules, stock dynamics, and the performance of spawning-per-recruit measures in protogynous stocks. Fishery Bulletin 103: 229-245.

Asoh, K., T. Yoshikawa and M. Kasuya (2001). Gonadal development and non-functional protogyny in a coral-reef damselfish, Dascyllus albisella Gill. Journal of Fish Biology 58: 16011616.

Bannerot, S.P., W.W. Fox and J. Powers (1987). Reproductive strategies and the management of snappers and groupers in the Gulf of Mexico and Caribbean. In: Tropical Snappers and Groupers: Biology and Fisheries Management (Polovina, J. J. \& Ralston, S., eds), pp. 561603. Westview Press, Boulder, Colarado. 


\section{R. R. M. K. P. Ranatunga and Shreemali Rathnayaka}

Bean, K., B. D. Mapstone, C. R. Davies, C. D. Murchie and A. J. Williams (2003). Gonad development and evidence of protogyny in the red-throat emperor on the Great Barrier Reef. Journal of Fish Biology 62: 299-310. doi: 10.1046/j.1095-8649.2003.00021.x

Currey, L.M., A.J. Williams, B.D. Mapstone, C.R. Davies, G. Carlos, D.J. Welch, C.A. Simpfendorfer, A.C. Ballagh, A.L. Penny, E.M. Grandcourt, A. Mapleston, A.S. Wiebkin and K. Bean (2013). Comparative biology of tropical Lethrinus species (Lethrinidae): challenges for multi-species management. Journal of Fish Biology 82: 764-788. https://doi.org/10.1111/jfb.3495

Ebisawa, A., (1990). Reproductive biology of Lethrinus nebulosus (Pisces: Lethrinidae) around the Okinawan waters. Nippon Suisan Gakkaishi 56: 1941-1954.

https://doi.org/10.2331/suisan.56.1941

Ebisawa, A. (2006). Reproductive and sexual characteristics in five Lethrinus species in waters off the Ryukyu Islands. Ichthyological Research 53: 269-280.

https://doi.org/10.1007/s10228-006-0345-3

Ebisawa, A. and T. Ozawa (2009). Life-history traits of eight Lethrinus species from two local populations in waters off the Ryukyu Islands. Fisheries Science 75: 553-566. https://doi.org/10.1007/s12562-009-0061-9

Grandcourt, E.M. (1999). The population biology of a selection of exploited reef fish from the Seychelles and Great Barrier Reef. Master's Thesis, School of Marine Biology and Aquaculture, James Cook University of North Queensland, Australia.

Grandcourt, E.M., T.Z. Al Abdessalaam, A.T. Al Shamsi and F. Francis (2006). Biology and assessment of the painted sweetlips (Diagramma pictum (Thunberg, 1792)) and the spangled emperor (Lethrinus nebulosus (Forsskål, 1775)) in the southern Arabian Gulf. Fishery Bulletin 104: 75-88.

Grandcourt, E.M., T.Z. Al Abdessalaam, F. Francis and A.T. Al Shamsi (2010). Reproductive biology and implications for management of the spangled emperor Lethrinus nebulosus in the southern Arabian Gulf. Journal of Fish Biology 77: 2229-2247. https://doi.org/10.1111/j.10958649.2010.02799.x
Grier, H.J. and R.G. Taylor (1998). Testicular maturation and regression in the common snook, Journal of Fish Biology 53: 521-542. https://doi.org/10.1111/j.1095 8649.1998.tb00999.x

Hoar, W. S. and D. R. Randall (1969). Fish Physiology: reproduction and growth bioluminescence, pigments and poisons, Volume 3. Academic Press, London. 485 p.

Jennings, S., M. J. Kaiser and J.D. Reynolds (2005). Marine Fisheries Ecology, Blackwell publishing company. Queensland, Australia.

Knight, J. T., G. L. Butler, P. S. Smith and R. N. E. Wager (2007). Reproductive biology of the endangered Oxleyan pygmy perch Nannoperca oxleyana. Journal of Fish Biology 71: 14941511.

Koenig, C.C., F.C. Coleman, L.A. Collins, Y. Sadovy and P.L. Colin (1996). Reproduction in gag (Mycteroperca microlepis) (Pisces: Serranidae) in the eastern Gulf of Mexico and the consequences of fishing spawning aggregations, in: Biology, Fisheries and Culture of Tropical Groupers and Snappers. ICLARM Conf. Proc. 48. pp. 307-323.

Kulmiye, A. J., M. J. Ntibav and S. M. Kisia (2002). Some Aspects of the Reproductive Biology of the Thumbprint Emperor, Lethrinus harak (Forsskål, 1775), in Kenyan Coastal Waters. Western Indian Ocean Journal 1: 135144.

Mackie, M. C. (2006). Anatomical changes to the gonad during protogynous sex change in the half moon grouper Epinephelus rivulatus (Valenciennes). Journal of fish Biology 69: 176186.

Mahmoud, H.H. (2009). Gonadal Maturation and Histological Observations of Epinephelus areolatus and Lethrinus nebulosus in Halaieb/Shalatien Area "Red Sea", Egypt. Global Vaterinaria 3: 414-423.

McPherson, G., L. Squire and J. O'Brien (1988). Demersal reef fish project 1984-85: age and growth of four important reef fish species. A report to the Great Barrier Reef Marine Park Authority. Queensland Department of Primary Industries, Fisheries Research Branch, Technical Report FRB 88/6. 38 p.

Marino, G., E. Azzurro, A. Massari, M. G. Finoia and A. Mandich (2001). Reproduction in the dusky grouper from the Southern 


\section{R. R. M. K. P. Ranatunga and Shreemali Rathnayaka}

Mediterranean. Journal of Fish Biology 58: 909927.

Marriott, R.J., N.D.C. Jarvis, D.J. Adams, A.E. Gallash, J. Norriss and S.J. Newman (2010). Maturation and sexual ontogeny in the spangled emperor Lethrinus nebulosus. Journal of Fish Biology 76: 1396-1414. https://doi.org/10.1111/j.10958649.2010.02571.x

McBride, R. S. and M. R. Johnson (2007). Sexual development and reproductive seasonality of hogfish (Labridae: Lachnolaimus maximus), a hermaphroditic reef fish, Journal of Fish Biology 71: 1270-1292.

https://doi.org/10.1111/j.10958649.2007.01580.x

McIlwain, J., G. V. Hermosa, M. Claereboudt, H.S. Al-Oufi and M. Al-Awi (2006). Spawning and reproductive patterns of six exploited finfish species from the Arabian Sea, Sultanate of Oman. Journal of Applied Ichthyology 22: 167176.

https://doi.org/10.1111/j.1439-

0426.2006.00723.x

Molloy, P. P., N. B. Goodwin, I. M. C. Cote, J. D. Reynolds and M. J. G. Gage (2007). Sperm competition and sex change: A comparative analysis across fishes. Evolution 61, 640-652.

Motlagh S. A. T., J. Seyfabadi, A. Vahabnezhad, M. Shojaei and M. Hakimelahi (2010a). Some Reproduction Characteristics and WeightLength Relationships of the Spangled emperor, Lethrinus nebulous (Lethrinidae) of the South Coastal of Iran (Persian Gulf and Oman Sea). Turkish Journal of Fisheries and Aquatic Scuences 10: 221-227. https://doi.org/10.4194/trjfas.2010.0210

Motlagh, S A T, A. Vahabnezhad, S.J. Seyfabadi, M. Ghodrati and Shojaei and M. Hakimelahi (2010b). Growth, mortality and spawning season of the spangled emperor (Lethrinus nebulosus Forsskal, 1775) in coastal waters of Hormozgan Province in the Persian Gulf and Oman Sea. Iranian Journal of Fisheries Science 9: 161-172.

Pears, R. J., J. H. Choat, B. D. Mapstone and G. A. Beggs (2007). Reproductive biology of a large, aggregation-spawning serranid, Epinephelus fuscoguttatus (Forsskal): management implications. Journal of Fish Biology 71: 795817.
Randall, J.E. (1995). Coastal fishes of Oman. University of Hawaii Press, Honolulu, Hawaii, $439 \mathrm{p}$.

Sadovy, Y. J. (1996). Reproduction in reef fishery species. In: Reef fisheries (Polunin, N. V. C. \& Roberts, C. M., eds). Chapman and Hall Series in Fish Biology and Fisheries 20, Chapman and Hall, London, UK. 15-59 pp.

Sadovy de Mitcheson, Y. and M. Liu (2008). Environmental and biodiversity impacts of capture-based aquaculture. In: (A. Lovatelli \& P.F. Holthus eds). Capture-based aquaculture. Global overview. pp. 5-39. FAO Fisheries Technical Paper. No. 508. Rome, 298 p.

Salem, M. (1999). Management of fishing in the Ras Mohammed National Park with special reference to the fishery for Lethrinus nebulosus (Forsskål, 1775). Ph.D. Thesis, University of York, York, UK.

Thresher, R. E. (1984). Reproduction in Reef Fishes. TFH Publ., Neptune City, NJ.

Young, P.C. and R.B. Martin (1982). Evidence for protogynous hermaphroditism in some lethrinid fishes, Journal of Fish Biology. 21: 475-484. https://doi.org/10.1111/j.10958649.1982.tb02853.x 